tions in favor of personal rights which are formulated in the Constitution and its amendments, but those limitations would exist rather by inference and the general spirit of the Constitution from which Congress derives all its powers than by any express and direct application of its provisions." By annexation then, the territory and the inhabitants become an integral part of the United States, to be governed by the people of the United States as expressed by Acts of Congress, Congress having power to pass all acts to regulate the government of the territories, subject only to the restriction that those acts must not be in conflict with the Constitution.

Philader,peia, March, I893.

\title{
THE EFFECT OF LAPSE OF TIME ON SUITS IN EQUTTY.
}

By George WhartoN PePPER, EsQ.

PERHAPs there is no branch of the law in which the courts have allowed themselves greater latitude of expression than that branch which is occupied with determining the effect of lapse of time upon the rights of plaintiffs who seek for equitable relief. It is obvious that radically different -considerations are applicable, on the one hand, to cases in which a trust relation subsists between plaintift and -defendant, and, on the other hand, to cases in which there is no such relation between the parties. Again, in cases in which a trust relation does subsist, it is clear that great importance must be attached to the distinction between trusts which arise from the operation of law upon a written instrument or from the express or tacit admission -of trusteeship by the defendant, and cases in which the trust arises purely by construction of law and in consequence - of facts and circumstances dehors the written instrument, -and independent of any admission on the part of the defend- 
ant. But an examination of the cases shows that the courts have shown themselves unusually ready to indulgein universal propositions in deciding particular cases, and they have not shrunk from asserting that mere lapse of time will bar no trusts whatever, when they happened to be deciding a case involving an express trust ; and they have alleged with equal positiveness, when it so happened that a constructive trust was before them for examination, that in all cases of trust the Statute of Limitations will be applied by a chancellor at the expiration of the period limited by the law.

The result of all this has been to create inuch confusion upon a subject that is not of itself difficult to understand. It is easy to trace the effect of this confusion upon the text writers, who have in general failed to recognize what are conceived to be the true principles applicable to the determination of these questions. Thus LEWIN, in his admirable work on trusts, while explicitly distinguishing between express and constructive trusts, and between cases in which laches is, and those in which it is not, imputable to the plaintiff, nevertheless fails to observe the distinction in the discussion of particular decisions. He cites Lord ALvaNLEX'S celebrated decision in Pickering $v$. Lord Stamford ${ }^{1}$ in the course of which that distinguished jurist remarked: "I know of no rule that has established that mere length of time will bar." Then LEWIN adds: "The doctrine laid down by Lord ALVANLEX in the case referred to, that mere length of time will not bar, requires some qualification." 2: $\mathrm{He}$ proceeds to instance cases of suits against a trustee to impeach a purchase, suits to set aside the purchase of a reversionary interest, suits to fix a defendant with a constructive trust, and suits asking relief for acts of waste or on the ground of fraud. In such cases, he says, a delay of Iess than twenty years may bar the plaintiffs' claim to relief. It is clear that none of these cases requires a modification of Lord ALVANLEX's statement. They are none of them cases.

12 VESEY, Jr., 282.

$2 * 872$. 
in which there is "a mere length of time." They are all of them cases in which either the positive bar of the statute is applied in obedience to the rule of law, or in which that - branch of the doctrine of laches which proceeds upon the ground of equitable estoppel is always applied by the chancellor.

Nor is LEWIN's three-fold classification of the cases in which lapse of time will operate as a bar an entirely satisfactory classification. The three bars which he recognizes are (I) a statute of limitation; (2) the presumption of something done, which, if done, is subversive of the plaintiff's rights ; (3) the ground of public policy or inconvenience of the relief. ${ }^{1}$ It is believed that an examination of the lucid opinion of Irord ALVANLEy, in Pickering v. Lord Stamford, will make it clear that there should be a four-fold division-a division which will be found to harmonize the great mass of judicial decisions upon lapse of time, and not inconsistent with any well-considered case. This classification may be thus stated: The chancellor will deny equitable relief to the plaintiff (I) if the defendant has held adversely to the plaintiff for more than the legal statutory period; (2) if the plaintiff, by acquiescence, has given his tacit consent to acts which he now seeks to impeach; (3) if the case is one in which, owing to the lapse of time, the Court will, according to certain definite principles, presume something to have been done which, if done, would bar the suit ; (4) if during the delay of the plaintiff there has been a loss of evidence, or by reason of the delay of the plaintiff the defendant or third persons have altered their position for the worse. In the first case the chancellor is said to act in obedience to the statutes of limitation. ${ }^{2}$ In the second case the chancellor proceeds upon the ground that a Court of Equity will not permit a plaintiff to obtain relief against the very transaction to which he was himself a party. In the

$1 * 864$.

2 "I think it is a mistake in point of language to say that Courts of Equity act merely by analogy to the statutes; they act in obedience to them." Lord REDESDALF, in Hovenden $v$. Annesley, 2 Sch. \& Lef., 630. 
third case the chancellor refuses relief, not because he really believes what is presumed, but, in the absence of evidence, for the purpose of quieting the possession. "It is said,". remarks Lord ERSKINE, "you cannot presume unless you believe. It is because there are no means of creating belief or disbelief that such general presumptions are raised." 1 In the fourth case- - to which, and to which alone, the term laches is applicable-the chancellor is governed by the familiar maxim "Vigilantibus non dormientibus aequitas subvenit." $\mathrm{He}$ will not assist the plaintiff, if the hardship upon the defendant is of the plaintiff's own making; in other words, the plaintiff is estopped. If a case cannot be reduced to one of these four categories no lapse of time, however long, will bar the plaintiff of his relief. "The mere lapse of time," said Mr. Justice STORY in Oliver v. Piatt," "constitutes of itself no bar to the enforcement of a subsisting trust."

Before examining each of these categories in detail, it will be convenient to state the case of Pickering $v$. Lord Stamford. A testator gave the residue of his personal estate to a charity, and thirty-five years after his death a bill was filed by the representative of one of his next of kin, praying that such part as consisted of money lent upon mortgage or other real security might be declared a void bequest under the statutes of mortmain which forbade testamentary gifts of interests in, and charges or encumbrances upon, real estate. The bill further prayed a distribution among the next of kin then living. Iord ALVANLEY approached the case from the point of view of sound common sense. He expressed himself as anxious to discourage stale claims, but he admitted that mere lapse of time would not bar. "Therefore, that being the case, I am to say whether, under the circumstances, a bar can be presumed." Having directed inquiries by a master, he came to the conclusion that no release or assignment could be presumed. Then he considered the case in the light of the doctrine of lackes, or, as he was pleased to say, the ground of incon-

${ }^{2}$ Hillaty $v$. Waller, 12 Vessey, 266.

${ }^{2} 3$ How, 4 Ir. 
venience. "If from the plaintiff's lying by it is impossiblefor the defendants to render the accounts he calls for, or it. will subject them to great inconvenience, he must suffer; or the Court will oppose, what I think the best ground, Public Convenience. The plaintiffs are so conscious of this that. they do not call on the trustees to account for what has been disbursed before any demand made. It appears that the trustees, who by their conduct have done themselves. great credit, have kept such accounts that there is no diffculty in finding the personal estate at the death of the testator. Therefore, not desiring to be understood to give any countenance to these stale demands, but upon the circumstance that there is nothing inducing great public or private. inconvenience, that the accounts are found, and that thetrustees are not called on to account for what has been dis-. bursed, I am bound to decide in favor of the plaintiffs." This should seem to be the proper attitude of mind in which to approach such cases, and it is submitted that every word of the opinion is sound law and good sense. Of course, the question of the bar of the statute did not arise, as the defendants admitted their trusteeship; and no question of acquiescence presented itself, as the plaintiff was not complaining of a breach of trust. .

The four propositions enunciated above may now be examined in order, and a few typical cases analyzed with a view to justifying the classification.

I. It was asserted above that the Statute of Limitations will never be applied in equity except in cases in which the defendant's holding is adverse to the plaintiff's. If this is true, it will follow that the statute will never bar a cestuti que trust of his relief against a defendant who has been constituted trustee ( $a$ ) either as the result of the intention of the parties expressed in a written instrument, or (b) as a result of the operation of law upon a written instrument independently of the intention of the parties, or (c) as a result of the defendant's own admission, whether that admission is expressed in words or implied from conduct. In all these cases an express or actual trust is said to exist; while to. 
the important class of trusts falling under $b$ the specific name resulting trust is applied. All trusts that are not express (or, as it is sometimes called, actual) are constructive. And to constructive trusts the statute is aiways appliéd.

Lord CAIRNS, in Cunningham v. Foot, ${ }^{1}$ defined an express trust to be "a trust which arises upon the construction of a written instrument." This, however, is too narrow a definition. In Life Association $v$. Siddal ${ }^{2}$ a trustee devised his estate to one Grace Thompson, subject to the payment of a legacy, so that the trust estate did not pass. She, although not a trustee or legally representing the trustee, assumed to act, and actually acted, as a trustee under the will. In the exercise of her assumed powers she committed a breach of trust: It was held that she was an express trustee, and that therefore the Statute of Limitations was no protection to her. "If," said Lord Justice TURNER, "she had by writing declared herself to be a trustee the trust in her could not have been otherwise than express, and her conduct is equivalent to her written declaration." This case, it will be observed, is a direct authority in support of proposition $c$. It would be better, as foreshadowed above, to define an express trust as a trust in which the trustee does not hold adversely to his cestui que trust. This definition is broad enough to cover that class of express trusts commonly called resulting trusts, since the trustee there admits his trusteeship, and holds with such powers and for such persons as the law designates. The fact that the identity of the real cestui que trust is a matter of dispute will not cause the Statute of Limitations to run in the trustee's favor. Thus, in Lister $v$. Pickford ${ }^{3}$ the trustees of a landed estate under a will erroneously collected and paid over the rents of an adjoining piece of land to the beneficial owners of the principal estate. Twentytwo years after the death of the testator the residuary

13 App. C., 984 .

23 DeG. F. \& J., 73.

${ }^{3} 34$ Beav., 506. 
devisee under the will began proceedings against the trustees to recover the land, upon the ground that it was included, on a proper interpretation of the will, in the residuary devise to the same trustees in trust for the plaintiff. The objection that the plaintiff's claim was barred by the statute was overruled, and the claim was sustained upon the ground that "a trustee who is in possession of lands is so in behalf of his cestui que trust, and his making a mistake as to the persons who are really his cestuis que trustent cannot affect the question." "The Statute of Limitations," said Lord CRANWORTH in Bullock v. Downs," "can have no operation in a case like the present, where the residuary estate has been set apart and appropriated on the trusts of the will, whatever those trusts may be; as between trustee and cestui que trust the statute does not apply."

In strict conformity to principle it has been held in England, where the Statute of Limitations excepts "express trusts" from its operation, that resulting trusts are also included in the exception. Thus, in the case of Salter v. Cavanagh, ${ }^{2}$ a testator devised certain lands to a trustee for a term of years upon trusts which did not exhaust the entire income of the property. Forty-seven years later the testator's heirs-at-law were held to be entitled to the surplus rents during the remainder of the term upon an express trust arising from the legal interpretation of the will. And in Brown $v$. Radford ${ }^{3}$ a bill to enforce a resulting trust arising from the conveyance of trust property without consideration was upheld by Sir GEORGE JESSEL after the lapse of one hundred and four years. ${ }^{4}$

16 F. of L., I.

2 I D. \& W., 668.

${ }^{3}$ W. N., I874, I24.

+ See the leading American case of Kane v. Bloodgood, 7 Johns. Ch., 90. This decision of Chancellor KENY's is peculiarly instructive, for as to some of the property in dispute he found that the holding had been adverse and applied the statute, while as to "share $4 \mathrm{I}$," he found that an express trust existed, and refused to apply the statute. He recognizes the distinction between actual, or express, and constructive trusts, when he 
In cases of constructive trust the possession of the defendant is necessarily adverse, and in all such cases the statutory bar will be applied. Thus, in Hovenden $v$. Lord. Annesley, ${ }^{1}$ which was the case of a constructive trust arising out of fraud, the lapse of sixty years was held to be a bar. Moth $v$. Atwood ${ }^{2}$ was a bill to set aside the conveyance of

says that the statute may be applied to the latter by analogy to the rule of law, since over them the courts of law and equity have concurrent jurisdiction; but that it will not apply to the former-the technical and continuing trusts which fall within the peculiar province of a coutt of equity. This mode of statement has been generally approved: Finney $v$. Cochran, I W. \& S., II2; Zacharias v. Zacharias, 23 Pa., 452; Heckert's Appeal, $24 \mathrm{~Pa}$, 482; Barton $v$. Dickens, $48 \mathrm{~Pa}$., $5 \mathrm{r} 8$.

For instances of "express trusts," to which the statute will not be applied, see Patrick $v$. Simpson, L. R., 24 Q. B. D., I28; Nugent v. Nugent, I. R., I5 Ir., 32I; Banner 0 . Berridge, I. R., I8 Ch. D.,.262; Burdick v. Garrick, I. R., 5 Ch. App., 233; Lewis v. Hawkins, 23 Wal., 126; In re Estate of Potter \& Page, 58 Pa., 465; Cox v. Dolman, 2 De G., M. \& G., 592; Att'y.-Gen. v. Brewer's Co., Mer., 495; Ward v. Arch, 12 Sim., 475; Ex parte Hasell; 3 V. \& C., 6I7.

Simmons $v$. Rudall, I Sim. (N. S.), Ir5, like Kane $v$. Bloodgood, is a most instructive case, on account of the different rulings in respect of the distinct pieces of property involved. The decision there was that threequarters of the propery in dispute was held by the defendants adversely to the plaintiff; that his remedy as heir-at-law was in ejectment; and that his claim was barred by the lapse of twenty-eight years. As to the remaining one-quarter of the property, it was declared that there had been an intestacy; that the defendants were, consequently, presumed to hold as trustees for the heir, and, as to this part of the property, the lapse of time was admitted to be no bar. In Attorney-General $v$. Fishmongers' Company, 5 M. \& Cr., I6, an attempt was made, after the lapse of four hundred years, to impeach the title of the defendants to certain tenements in Iondon, and to show that the same was held by the defendants as trustees. Lord CorrenHaM held that the lapse of time would be no bar if it were clear that the will under which the company claimed had created a trust. As the plaintiff relied upon matters extrinsic to the will, and as it was doubtful whether the company was not interided to take the whole beneficial title, the lapse of four hundred years was held to be a bar.

$1_{2}$ S. \& I., 636 .

${ }^{2} 5$ Vesey, Jr., 68r. For other cases of constructive trusts see-Champion $v$. Rigby, I R. \& M., 53 ; Roberts $v$. Tunstall, 4 Hare, 257 ; Ashhurst's Appeal, $60 \mathrm{~Pa}$., 29o. In this last case Mr. Justice Srrong said: "Certain it is that no express trust is either charged or proved." Other cases of adverse possession are Cholmondely $v$. Clinton, 2 J. \& W. r4r; Elrnendorf $v$. Taylor, to Wheat., I52; Townshend $v$. Townshend, I Cox, 28; Bowman $v$. Wathen, I How., I89; Hamilton v. Hamilton, I8 Pa., 20. 
a reversion on the ground of inadequacy of consideration. As this was a constructive trust (although, in point of fact, the Court was of opinion that the transaction was characterized by good faith), the lapse of the statutory period was held to bar the plaintiff's right by analogy to the rule of law.

II. The defense of acquiescence is available only in those cases in which the cestui que trust is proved by the defendant to have been fully cognizant of the facts of the case, and to have been aware of his legal right to dispute the dealings in which he is alleged to have acquiesced. ${ }^{1}$ "Length of time, where it loes not operate as a statutory or positive bar," says Lord Justice TURNER in Life Association $v$. Siddal, " "operates, as I apprehend, simply as evidence of assent or acquiescence. The two propositions of a bar by length of time and by acquiscence are not, as I conceive, distinct propositions. They constitute but one proposition, and that proposition, when applied to a question of this description, is that the cestui que trust assented to the breach of trust."

The question whether or not a plaintiff has acquiesced is a delicate one for the chancellor to determine. No more definite rule can be laid down than the general statement that the burden. rests upon the defendant to prove that the plaintiff was fully apprised of every fact and circumstance which might reasonably have influenced him to assert his rights. A typical case is Farrant $v$. Blanchford, ${ }^{3}$ where, in spite of the fact that acquiescence was not an inference from conduct but was evidenced by a written release, Sir JoHN ROMILIX held that the defendant had not discharged the burden of proof that rested upon him, and refused to . bar the plaintiff's suit. On appeal this decision was reversed ${ }_{2}^{4}$ and the two views of the same case taken by the

1 Cockerel $v$. Cholmondely, I R. \& M., 425; Marker z. Marker, 9 Hare, 16.

${ }^{2}$ De G. F. \& J., 73. .

3 II W. R., I78.

I De G. J. \& S., 107. In delivering his opinion, Sir JOHN ROMILLY said: "This is a case in which, in my opinion, the plaintiff is entitled to a 
learned judges make the decision both interesting and important.

III. Lord ERSKINE's statement of the ground upon which the Court proceeds in cases of presumption has already been quoted. ${ }^{1}$ It is to be noted, in the first place, that a presumption-that is to say, an assumption-will never be raised except for the purpose of quieting a possession which is adverse to the plaintiff, and that, accordingly, the doctrine of presumption seems to have no place as between the parties to an express trust. After a lapse of time, it is. a rule of property, founded upon considerations of policy, that a presumption will arise that a legacy has been paid, that a debt has been satisfied, or that a release has been executed. But where the defendant admits his trusteeship qua the property which is actually in his hands, the prerequisites of a presumption are not present; there can be no presumption of payment or satisfaction, for the trustee holds the property; and there can be no presumption of a

decree. In the first place, there was originally a clear breach of trust by Mr. Bidwell, the trustee, under which he would be liable to make good the amount of the trust money unless something has been done by the plaintiff to intercept his right to that equity. Now, I have to consider how he could intercept his right to that equity. It must be either by reason of lapse of time-that is to say something that he has not done-or by reason of something that he has done, or by the combined effect of the two. I will consider them separately. As to the lapse of time, that alone would be no bar in this case. The plaintiff was $2 \mathrm{I}$ in March, $185 \mathrm{I}$; the bill was filed, I think, in April, I86I; and if that were unexplained, and it were a mere breach of trust, though he knew of it at the time, that would not bar his right to come here to have the breach of trust set right." Then he proceeds to examine a release of liability executed by the plaintiff to the defendant, and finds that it is without effect as being voluntary and without consideration. He proceeds : "If it were an instrument under seal, and - if Mr. Bidwell relied upon it under those circumstances, it would be necesaary for him to show that the father, or somebody on his behalf, duly explained to the son the circumstances of the case, and that he had full information upon the subject of what the value was of the proposed secnrities, and that all those circumstances were truly and fully explained to the plaintiff before he signed the document." On appeal the decision was reversed, not because the learned judge below had misstated the law, but on the ground that sufficient knowledge of the facts and of his rights. had been brought home to the plaintiff at the time he signed the release.

${ }^{3}$ Supra, p. $3^{22}$. 
release, for the defendant admits that he holds only the legal title. Again, where a presumption might exist, and although it is said that presumptions are favored in law and should not be rebutted by slight evidence, it must be remembered that the presumption is only a presumption. It is inconceivable, for example, that if a creditor were, in the absence of a Statute of Limitations, to bring suit after a lapse of twenty years, any presumption of payment would arise where by the terms of the evidence of indebtedness sued upon it was provided that payment should be made only upon a surrender of the document.

IV. In discussing the question of laches it is particularly important to bear in mind the principle so often insisted upon, that mere lapse of time is no bar to the assertion of a pure equitable right. If the statute is inapplicable, if no presumptions exist, or if they have been rebutted, and if the plaintiff is not seeking to impeach a transaction, but-merely to enforce an express trust-so that there can be no question of acquiescence-then he will not be barred by lapse of time unless, as the result of his delay, (I) the position of the defendant or of an innocent third person has become irreparably altered for the worse; or (2), it has become impossible to do complete justice between all the parties by reason of the death of witnesses, the destruction of documents, or the loss of evidence. Under the former head it is interesting to note the language of the Master of the Rolls in Wollaston $v$. Tribe:" "Great stress was laid on the lapse of time, but I think nothing of that, because all the persons interested are in the same state now as they were then. If there had been any dealing which had altered the state of matters, that might have raised a question, but there is nothing of the sort." "The delay of the complainant in seeking redress constitutes no defense," so said the Court in Daggers $v$. Van Dyck." "It is only when the complainant has slept over his wrongs so long that if relief be given to him

1 L. R., 9 Eq., 44.

37 N. J. Eq., 130. 
great wrong will be done to the defendant, that laches constitutes a complete defense."

It follows that in the case of a constructive trust the defense of laches is peculiarly available for the defendant. ${ }^{5}$ In such a case the possession of the defendant is necessarily adverse, and almost invariably a delay on the part of the plaintiff will result in the defendant's altering his position for the worse. Besides this, there are those considerations which belong more properly under the second head of laches-loss of evidence, etc. - for in the case of a constructive trust the trust is raised by matter dehors the written instrument and independently of the defendant's own admission, and the proof is always more or less complicated.

Under the second head of laches, Cranmer v. McSwords ${ }^{2}$ is an important case. The Court there states the important elements of laches to be the death of parties, the intervention of innocent third parties, such a loss of evidence as to render it difficult to do justice, and the fact that evidence consisted of parol testimony doubtful by reason of age. The Court called attention to the fact that when these elements exist, relief is often denied within a period of twenty years, and that when they have not existed, relief has often been granted after a period much longer than twenty years. Accordingly, in the United States 0 . City of Alexandria, ${ }^{3}$ after a delay of forty years, a bill for the conveyance of stock was sustained on the ground that in such a case, as there had been no substantial change of circumstances, equity would enforce a claim of long standing as readily as one of recent origin. It will be recollected that a portion of the decision in Pickering $v$. Lord Stamford is referable to this head; and side by side with it may be placed the case of Thorndike $v$. Loring, ${ }^{4}$ where a resulting trust in favor of the next of kin was enforced after the lapse of

\footnotetext{
'Ashhurst's Appea1, 6o Pa., 315; Evans'. Appeal, 81 Pa., 278.

224 W. Va., 6or.

${ }^{3}$ I9 Fed. Rep., 609.

45 Gray, 39r.
} 
twenty-eight years, as the rights of the plaintiff rested exclusively upon the interpretation of a written instrument and the very fund which he claimed subsisted intact in the hands of the trustees.

Upon the whole, therefore, it is contended that LEWIN is wrong, and that Lord ALVANLEY is right in his assertion that no rule has established that mere length of time will bar a suit in equity. If a case is not capable of being reduced to one of the four categories developed above, the mere circumstance that the claim is of long standing will not deprive the plaintiff of his relief. A thousand years in the sight of the Chancellor are but as yesterday.

Phil,adel,Phia, March, ' 1893. 